\title{
EFFECT OF SOCIAL AMINITIES ON THE RELATIONSHIP BETWEEN BANK LOAN AND ARABLE LAND IN NIGERIA: THEORETICAL FRAMEWORK
}

\author{
Dr. Adam Ibrahim Muhammad ${ }^{1}$, Dr. Ahmed Ibrahim Mohammed², Hayatuddin Hamza Safiyo², Muhammad \\ Bello Jakada ${ }^{3}$, Suleiman Bashiru Sajo ${ }^{2}$ \\ ${ }^{1}$ Department of Economics, Faculty of Arts and Social Sciences \\ Federal University, Dutse, Jigawa State, Nigeria. \\ ${ }^{2}$ Department of Banking and Finance, Faculty of Management Sciences \\ Federal University, Dutse, Jigawa State, Nigeria. \\ ${ }^{3}$ Department of Business Administration, Faculty of Management Sciences \\ Federal University, Dutse, Jigawa State, Nigeria.
}

DOI: http://dx.doi.org/10.38193/IJRCMS.2021.3306

\begin{abstract}
The purpose of this study is to investigate the relationships between bank loan and Arable land in Nigeria, with the effect moderating of social aminitie. Literature was extensively reviewed in arable land and other related fields for better understanding of past, present and future needs in the study area. Although their relationships have generated considerable scholarly interest, few studies have actually been conducted between social aminities as moderating variable with Bank loan and arable land in Nigeria. farming is essential to economic growth in Nigeria and it is a major source of employment and poverty reduction. Based on a theoretical consideration, a theoretical framework was proposed to examine the relationships between study variables. The literature reviewed on this study reported that bank loan and arable land found related while social aminities was moderates their relationship. Finally, study's implications for theory and practice, conclusions as well as direction for future research were provided and discussed.
\end{abstract}

KEYWORDS: Bank loan, Arable land, Social Aminities, financial Institutions and Ministry of Agriculture.

\section{INTRODUCTION}

Arable land has an important feature on making the advancement of the agricultural production and economic growth. On the other hand, if there is no access to land, agriculture cannot adequately develop, even if and only if technical expertise, financing or marketing are available. Therefore, it is very essential for the agricultural enterprises and financial institutions to support the existence of a minimum level of arable land development. Since, arable land is featured the attainment of long-term profitability in agriculture and agro-business activities (Ngaruko, 2014). Additionally, it is a fundamental resource for ensuring agricultural production and security (Chisasa, 2014b, Ogunbado $\&$ Ahmed, 2015). Arable land remained a vehicle for poverty reduction in the developing countries. 
Arable land serves as a machinery of economic growth of the most populous country of Africa called Nigeria in terms of agricultural production. Furthermore, in the year 2021, Nigerian population estimated at 206,139,569, whereas 70 percent remain solidly depended on agriculture as their main source of socio-economic priorities as such includes: income, food, employment, market and social amenities among others (Philip, Nkonya, Pender \& Oni Nkonya; Sakumbade, 2009; National Population Commission (NPC), 2015). Similarly, federal government ministry of agriculture and Central Bank of Nigeria $(\mathrm{CBN})$ as well as the worthy partners in an agricultural development programme. The CBN and worthy partners established various agricultural programmes and schemes in order to improve arable landthrough agricultural financial services (Philip et al., 2009; Odufote, 2012, CBN, 2014).

More so, federal government and other partners were set to improve arable landthrough provision of agricultural financial services (Philip et al., 2009). Atagana and Kanu (2014), Holdeny and Harold (2010) viewed that Bank loan remain a key player towards advancement of productive land. As the name implies Bank loan is the direct financial aspect. While, land is the the top layer of the earth's surface that contained nutrients for the growing of plants. It is also provided space for livestock, poultry, and fisheries as well as agribusiness activities (Chamber, 1988).

Despite the importance of arable land in the economic growth of Nigeria as well as the initiatives of both public and private organizations toward improving the sector. Yet, the problem of access to Bank loan to boost arable land is persist, since, the period of the oil boom of 1970's where Nigeria has started experience such problems. Although, process and structural problems in agricultural production cannot be solved with consideration of social aminities which is a tool for stimulating farmers to perform at their highest level (Ahugwu, Haruna \& AbdusSalam, 2014). Collier and Dercon (2014) stipulated that social aminities in the area of agriculture include: tractors, herbicides, harvesters, farmers' education and training, modern storage facilities, good road, transportation and communication among others are the best targets toward supporting arable land to produce higher output. Based on the contributions of the social aminities the current investigation considered social aminities as a moderating variable on the relationship between Bank loan and arable land in Nigeria.

\subsection{Problem Statement}

Nigeria has a favourable climatic condition for supporting arable land. As 84 million arable land hectares covers the country which provides opportunity to full and part time farming system as well as industrial and commercial activities in Affica. As farming system is divided into: subsistence and Commercial based mode of production. Subsistence farmers serves as the majority, but faces the challenges of inadequate Bank loan which resulted to inadequate farm machineries and equipments among others (Ogunbado \& Ahmed, 2015). In line with the argument of the Cobb-Douglas theory of the production function, it revealed that, sufficient production input is subject to the proportional and 
significant increase in the production output (Chambers, 1988; Chisasa, 2014a). However, Nigerian subsistence farmers suffers from the issues related to insufficient Bank loan to the extent that farmers are abandoning the practice farming system. According to Oludufe (2012) the current model is essentially tied to the problems such as: mismanagement and corruption as well as inconsistent findings. In line with the argument of Baron and Kenny's (1986) that the inclusion of a moderating variable is necessitated in the existence of inconsistent findings on the relationship between the independent and the dependent variables. Therefore, this study incorporated Social aminities to moderate the relationship between Bank loan and Arable land. Based on these this paper developed the following research objectives.

\subsection{Objectives of the Study}

The research is set to examine the relationship and moderating effects of Social aminities on the relationship between Bank loan and Arable land. Specifically, the research aims to achieve the following objectives: -

1. To examine the relationship between Bank loan and Arable land in Nigeria.

2. To examine the moderating role of Social aminities on the relationship between Bank loan and Arable land in Nigeria.

\section{LITERATURE REVIEW}

\subsection{Arable Land}

Arable land can be seen as a major factor of agricultural production. It is also refers to a fertile portion of soil being utilized for a purpose of crop planting and space occupied for rearing of animals, poultry, fisheries and forest reservations. It is equally, remains a factor of production and served as a pillar of some kind of agricultural production, including processing and marketing (Kan, Haim, Rapeport-Rom $\&$ Schechter, 2008). Similarly, arable landis a gift from Allah to the mankind for the purpose of crop growing and animal rearing as a source of comfort, safety and quality of life. It is also a fundamental element of plant and animal life. Moreso, the said land is support food supply and raw materials to the industries. Arable land or soil utilizations remain a vehicle for providing food to the man and feed to the animals and reservation of forest for human satisfaction and economic growth (Ayegba \& Ikani, 2013; Chisasa, 2014a).

\subsubsection{Bank Loan:}

Loan defined is an important instrument for improving the welfare of the poor directly through smoothening and reduces their vulnerable short-term of an income. In addition, Bank loan can be defined as a total amount of money available to lend out to the needy individual or group of farmers with the agreement of repayment over a period of time in a future (Chisasa, 2014a). It is also the way and manner of enhances the productive capacity of the poor through financing their investment in 
relation to human and physical capital (Anthony, 2010). It is equally, recognized as an outflow of fund to the needy farmer with the intentions of making the repayment with some additional fund or reward for the utilization of the fund over a period of time. And, it is can be a procedure of gaining command of money, goods and services for the purpose of agricultural activities based on repayment conditions (Simtowe \& Lestari, 2015).

More so, bank loan is recognised as the main requirement and core factor in the development and advancement of arable land and economic growth (Ahiakpor \& Asmah, 2012). It plays a very critical part in the agricultural growth and development. The system allows farmers to meet their needs and economies of scale through the uses of modern technologies that enable them to improve their production and market (Ijere, 1998). Equally, agricultural credit is an effort to increase agricultural yield or output through enabling farmers to achieve his/ her socioeconomic and development objectives. In addition, the availability of the bank loan leads poor farmers to be efficiently played a vital role in the economy (Onyechanya \& Ukoha, 2007; Eyo, 2008).

\subsubsection{Relationship between Bank Loan and Arable Land}

Wilson and Featherstone and Langemeier (2013) established relationship between the profitability of the loan compared to farm output of a single and multiple farm loan system of Kinsas farm in the United States of America. Chisasa (2015) revealed a positive result in South Africa. In another study Chisasa (2014) reported a positive credit and arable landin South Africa. Tibi and Edebiri (2015) reported a positive and significant relationship between bank loan and agricultural production through investigation of farmers' access to micro credit and poverty alleviating in the Ethiope East Area of Delta State Nigeria. Ahiakpor and Asmah (2012) reported a positive relationship between bank loan and arable land in Nigeria. Adeola and Ikpesu (2014) reported a positive, but the weak result between farm bank lending and arable land in Nigeria. Chisasa and Makina (2014) revealed a positive finding between credit and agricultural production in South Africa.

On the other hand, Faridi, (2012) reported a negative result from his study entitled finance and agricultural export in Pakistan. Additionally, Adetiloye (2012) reported a negative relationship between credit and arable land in Nigeria. Omonijo, Toluwase, Oludayo and Uche (2014) reported a negative relationship between credit and arable land in Isan-Ekiti, Nigeria. Reyes, Lensink, Kuyvenhoven and Moll (2012) reported a negative relationship between bank loan and arable land in Peru. In addition, Chasisa (2015) studied the econometric bank lending analysis and arable land in South Africa. Ammani (2012) reported a positive result in his study entitled investigate the relationship between formal credit supply and agricultural production in Nigeria. Kaleem and Abdul Wajid (2009) reported a positive finding from their study in agriculture Development Bank of Pakistan. 
Hypothesis 1: Is there any relationship between Bank loan and social aminities in Nigeria?

\subsection{Social Aminities:}

Social aminities can refer to the facilities use to standardize the lifestyle of the individual or group of people to fill the necessary prerequisite for the modern style of production. The necessary facilities in terms of production and distributions include; human capital and schools for labour and farmer training, farmers' income, hospital, good road, market, modern equipments among others (Agatana \& Kalu, 2014). Furthermore, arable land social aminities can be described as a modern farming science and employ technology to improve agricultural productivity. Among the modern farm equipments and machineries include: storage facilities, tractors, harvesters, planters, fertilizer, insecticides, farmer education and training, extension workers among others. In addition, the presence of reliable farm social aminities resulted in the increase in both outputs per capita and output per unit of land. Hence, farm facilities are the key players by reducing transaction costs in terms of input, output, processing and marketing of agricultural activities within (Murphy, 2015).

\subsubsection{Relationship between Bank loan, Social Aminities and Arable Land}

It is highly recognized that social aminities in arable land remains the necessary ingredients for precondition for gathering of capital and rise in arable land (Mohammed et al., 2016). This is related to the improvement of the social aminities of the rural communities in the terms of providing modern farming equipments and technologies that includes: electricity, health centers, transportation and communication among others. Ammani (2012) reported a positive and significant relationship between technology and agricultural productivity in Nigeria. Chisasa (2014a) established negative relationship between human labour as a farm social aminities and arable land on the performance of smallholder farmers in South Africa.

Felloni, Wahl, Wandschneider and Gilbert (2001) studied revealed mixed results on the relationship between social aminities and arable land. Temu, Nyange, Mttee and Kashasha (2013) reported a negative relationship between farm farm social aminities and arable land in Tanzania. In addition, Ngaruko (2014) established negative relationship between educations and arable land in Tanzania. Okuthe, Ngesa and Ochola (2013) established a positive relationship between technological social aminities and the growths of arable land of sorghum in South Western Kenya. Furthermore, Mohammed, Bashir and Ogunbado (2016) studied bank loan and arable land in Nigeria.

Hypothesis 2: Does Social aminities moderates the relationship between Bank loan and Arable land in Nigeria? 


\subsection{Theoretical FrameWork}

INPENDENT VARIABLES

DEPENDENT VARIABLE

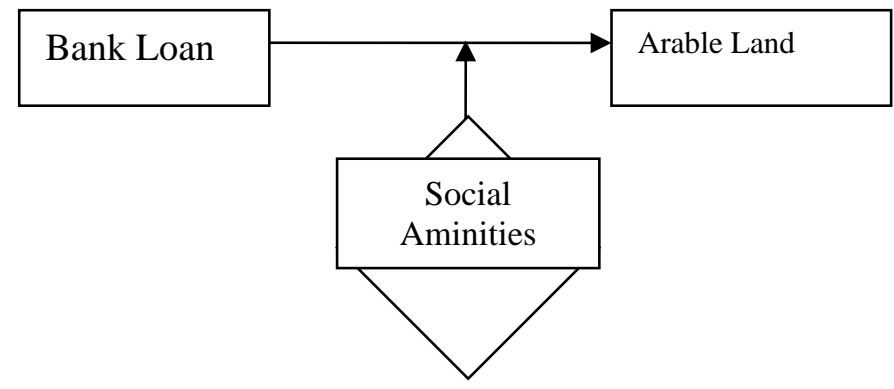

MODERATOR

The above theoretical framework as indicated the directions of the arrows which explained the relationship between agricultural Bank loan and productive as well as Social aminities as the moderator on the relationship between independent and dependent variables and this in line with the theory of production based on Cobb-Douglas (1929) Production function established the relationship between agricultural input and output (Chambers, 1988; King \& Levine, 1993; Anthony, 2010; Chisasa, 2014).

\section{UNDERPINNING THEORY}

This research is relevant to the theory of production as the basic objective of the land productivity is to ensure sustainable production input and output for the economic growth. Similarly, social aminities is a fundamental tool being widely used in facilitating agricultural productivity for sustainable economic growth and development (Chisasa, 2014a). Therefore, it is relevant here to consider the theory of production based on the production function of Cobb Douglas (1928), so as to work as an underpinning theory in this research. Since, theory of production is concerned with the measurement of the physical production through measuring the changes in the determinants or factors or input of production of the volume of production output (Musafiri \& Muzabaev, 2014). Theoretically, the framework of the research can be established the relationship between the Bank loan and arable land as well as the social aminities serves as the moderating variables in figure 3.1

\subsection{Research Methodology:}

This study is a based-on library materials. Statistics were not involved. This indicates that the methodology used is the qualitative research approach. 


\section{Implications:}

The finding of this research has a proposed practical implication for the agricultural sector in Nigeria. Firstly, the proposed results based on literature reviewed suggest that perceptions of Nigerian farmers on the social aminities are important toward promoting arable land in Nigeria. Secondly, the findings suggest that Bank loan is related to arable land to yeald more farm produce. In particular, the moderating role of the proposed social aminities can maximize the tendencies of farmers performance.

\section{Conclusions:}

The literature of this study revealed the existence of positive relationship between Bank loan and arable land as well as social aminities moderates the relation between the study variables. The theory yeald the study framework as it stipulated that, arable land is a function of technical efficiency of Bank loan for the economic growth. Whereas, social aminities serves as an essential facility between the relationship of the Bank loan and arable land in the economic growth of Nigeria. Thus, the ministry of agriculture could consider social aminities as a selection criterion when making decisions. Taken together, the present study has provided additional evidence to the growing body of knowledge concerning the moderating role of social aminities on the relationship between Bank loan and arable land.

\section{Recommendations:}

Results from this study supported the key theoretical propositions. In particular, the current study has successfully found literature that answered all of the research objectives despite some of its limitations. While there have been many studies examining the underlying causes of declined of arable land, however, the present study addressed the theoretical gap by incorporating social amnities as a significant moderating variable. In addition to the theoretical contributions, the results from this study provide some important practical implications to the Nigerian government through the ministry of agriculture, financial institutions and stake holders as well as nongovernmental organizations (NGOs). Future research should consider informal loan and arable land in Nigeria.

\section{REFERENCES}

Aburaida, K. M. M. (2014). Rural Finance as A Mechanism For Poverty Alleviation In Sudan, With An Emphasis On „Salam “Mode. European Scientific Journal, 7(26).

Adetiloye, K. A. (2012). Agricultural financing in Nigeria: an assessment of the Agricultural Credit Guarantee Scheme Fund (ACGSF) for food security in Nigeria (1978-2006). Journal Economics, 3(1), 39-48.

Adeyemi, A. (2013). Assessing the Effects of Taxation System on Nigerian Economic Growth. In Proceedings of 2013 International Conference on Poverty Alleviation Income Redistribution \& Rural Development in Developing Countries (p. 185). 
Ador, S. F., Shafiai, M. H. M., \& Ismail, M. A.(2014). Islamic Micro Financing for Sustainable Oil Palm Farming: Case of Independent Smallholders Prosiding Perkem ke-9 (2014) 1 - 13 ISSN: 2231-962X.

Ahangar, G. B., Padder, M. U., \& Ganie, A. H. (2013). Islamic banking and its scope in India. IRACST-International Journal of Commerce, Business and Management (IJCBM), 2(5), 266269.

Ahiakpor, F., \& Asmah, E. E. (2012). A Brief Survey of the Literature on Microfinance and Agriculture. Faculty of Social Sciences, University of Ghana, Legon, 9(1), 73.

Ahmed, H. (2014). Islamic Banking and Shari'ah Compliance: A Product Development Perspective. Journal of Islamic Finance, 3(2), 15-29.

Ahungwa, G. T., Haruna, U., \& Abdusalam, R. Y. (2013). Trend Analysis of the Contribution of Agriculture to the Gross Domestic Product of Nigeria (1960-2012).

Akoum, I. F. (2008). Globalization, growth, and poverty: the missing link. International Journal of Social Economics, 35(4), 226-238.

Allahyari, M. S., Poshtiban, A., \& Koundinya, V. (2013). Effective Factors on Agricultural Land Use Change in Guilan Province, Iran. Mediterranean Journal of Social Sciences, 4 (11), 744.

Ammani, A. A. (2012). An Research into the Relationship between Agricultural Production and Formal Credit Supply in Nigeria. International Journal of Agriculture and Forestry, 2(1), 4652.

Ammani, A. A. (2013). Impact Of Market-Determined Exchange Rates On Rice Production And Import In Nigeria. International Journal of Food and Agricultural Economics (IJFAEC), 1.

Ammani, A. A. (2013). Impact of Market-Determined Exchange Rates on Rice Production And Import In Nigeria. International Journal of Food and Agricultural Economics (IJFAEC), 1.

Anthony, E. (2010). Agricultural Credit and Economic Growth in Nigeria: An Empirical Analysis. Approach with Special Reference to Poverty Eradication in Pakistan. International Journal of Economics, Management and Accounting, 20(1).

Asogwa, B. C., \& Okwoche, V. A. (2012). Marketing of agricultural produce among rural farm households in Nigeria: The case of sorghum marketing in Benue State. International journal of Business and social science, 3(13), 269-277.

Asogwa, B. C., \& Okwoche, V. A. (2012). Marketing of agricultural produce among rural farm households in Nigeria: The case of sorghum marketing in Benue State. International journal of Business and social science, 3(13), 269-277.

Atagana \& Kalu, C., (2014) Evaluation of Fund for Agricultural Credit Guarantee Scheme in Nigeria: A Tool for Economic Growth and Development.

Awe.A.A (2013). Mobilization Of Domestic Financial Resources For Agricultural Productivity In Nigeria. Australian Journal Of Business And Management Research Vol, 2(12), 01-07.

Ayegba, O., \& Ikani, D. I. (2013). An Impact Assessment of Agricultural Credit on Rural Farmers in Nigeria. Research Journal of Finance And Accounting, 4(18), 80-89. 
Ayub, M. (2007). Understanding Islamic finanance. West Sussex Willey \& Sons Ltd.

Baron, R. M., \& Kenny, D. A. (1986). The moderator-mediator variable distinction in social psychological research: Conceptual, strategic, and statistical

Bello, G.I (2006). An analysis of the viability of Islamic Banking in Nigeria, Nigeria. Usman Dan fodio University Sokoto-Nigeria (Doctoral dissertation (C) Garba Bello)

Bhalla, S. S., \& Roy, P. (1988). Mis-specification in farm productivity analysis: the role of land quality. Oxford Economic Papers, 40(1), 55-73.

Central Bank of Nigeria (CBN). Report of the Activities of the Business Unit for the Month Of August, 2014 Development Finance Department (Dfd) - Report of the Activities of the Business Unit for the Month of August, 2014s.

Chambers, R. G. (1988). Applied production analysis: a dual approach. Cambridge University Press.

Chin, W. (2010). How to write up and peport PLS analyses. In V. Esposito Vinzi, W. W. Chin, J. Henseler \& H. Wang (Eds.), Handbook of Partial Least Squares (pp. 655-690): Springer Berlin Heidelberg.

Chin, W. W. (1998a). The partial least squares approach to structural equation modeling. In G. A. Marcoulides (Ed.), Modern Methods for Business Research (p. 295-336). Mahwah, New Jersey: Laurence Erlbaum Associates.

Chin, W. W. (1998a). The partial least squares approach to structural equation modeling. In G. A. Marcoulides (Ed.), Modern Methods for Business Research (p. 295-336). Mahwah, New Jersey: Laurence Erlbaum Associates.

Chin, W. W. (1998b). The partial least squares approach for structural equation modeling. In George A. Marcoulides (Ed.), Modern Methods for Business Research, Lawrence Erlbaum Associates, Lawrence Erlbaum Associates, Mahwah, NJ, 295-336. 232.

Chin, W. W. (2010). How to write up and report PLS analyses. In Esposito, V., et al. (eds.), Handbook of Partial Least Squares (655 - 688). New York: Springer- Verlag.

Chisasa, J. (2014a). An Econometric Analysis Of Bank Lending And Arable land In South Africa: A Survey Approach. Journal of Applied Business Research (JABR), 31(1), 163-174.

Chisasa, J. (2014a). An Econometric Analysis Of Bank Lending And Arable land In South Africa: A Survey Approach. Journal of Applied Business Research (JABR), 31(1), 163-174.

Chisasa, J. (2015). An Econometric Analysis of Bank Lending And Arable land In South Africa: A Survey Approach. Journal of Applied Business Research, 31(1), 163.

Chisasa, J. A (2014b). Diagnosis of Rural Agricultural Credit Markets In South Africa: Empirical Evidence From North West And Mpumalanga Provinces.

Chisasa, J. A (2014b). Diagnosis of Rural Agricultural Credit Markets In South Africa: Empirical Evidence From North West And Mpumalanga Provinces.

Chisasa, J. A (2014c). Diagnosis of Rural Agricultural Credit Markets in South Africa: Empirical Evidence from North West And Mpumalanga Provinces. Banks and Bank Systems, Volume 9, Issue 2, 2014. 
Chisasa, J., \& Makina, D. (2014). A diagnosis of rural agricultural credit markets in South Africa: empirical evidence from North West and Mpumalanga provinces. Banks and Bank Systems, 9(2), 100-111.

Collins, E. J. T. (1976). Migrant labour in British agriculture in the nineteenth century. The Economic History Review, 29(1), 38-59.

Commodity Murabahah House (CMH) (2010). flexibility and access of the international financial institutions (http://www.bnm.gov.my).

Dandago K.I (2005). Beyond Slogans, How states Hold the Ace for Nigeria's Industrialisation. ISBN: 978-8130- 05-4.

Dandago, K.I, AD. Muhammad \& U.A.Oseini (2013). Essentitials Of Islamic Banking And Finance In Nigeria. Publish in Abuja ( p: p. 353-358)

Dandago,K.I, AD. Muhammad \& U.A.Oseini (2003). Essentitials Of Islamic Banking And Finance In Nigeria. ISBN:978-978-8130-33-X

Davidova, S., Fredriksson, L., Gorton, M., Mishev, P., \& Petrovici, D. (2012). Subsistence farming, incomes, and agricultural livelihoods in the new member States of the European Union. Environment and Planning C: Government and Policy, 30(2), 209-227.

Eyo, E. O. (2008). Determinants of Success of Micro-Finance Schemes Serving the Agricultural Sector in Akwa Ibom State, Nigeria. Pakistan Journal of Social Sciences, 5(2), 173-176.

Falk, R. F., \& Miller, N. B. (1992). A primer for soft modeling. Ohio: The University of Akron Press.

Faridi, M. Z. (2012) reported a negative result between finanace and agricultural in Pakistan.http://www.iiste.org/Journals/index.php/PPAR/article/viewFile/24951/25554.

Fornell, C., \& Bookstein, F. L. (1982). Two structural equations models: LISREL and PLS applied to consumer exit-voice theory. Journal of Marketing Research, 19, (4), 440-452.

Fornell, C., \& Larcker, D. F. (1981). Evaluating Structural Equation Models with unobservable variables and measurement error. Journal of Marketing Researc 18, 39-50.

Goi, C. L. (1970). E-Banking in Malaysia: Opportunity and challenges. The Journal of Internet Banking and Commerce, 10(3), 1-11.

Hair, J. F., Black, W. C., Babin, B. J., \& Anderson, R. E. (2010). "Multivariate data analysis": A global perspective. New Jersey: Pearson Education, Inc.

Hair, J. F., Hult, G. T. M., Ringle, C. M., \& Sarstedt, M. (2014). A primer on partial least squares structural equation modeling (PLS-SEM). Thousand Oaks: Sage Publications.

Hilmy, H. A. (2013). Introducing Salam as an alternative financing tool for paddy field cultivation in Sri Lanka (special reference to Eastern province). Soth Eastern University of Sri Lanaka.

Hoellinger, F. (2011). Agricultural Finance-Trends, Issues and Challenges. Deutsche Gesellschaft für Internationale Zusammenarbeit (GIZ) GmbH. Bonn. Germany.

Holden, S. T., \& Otsuka, K. (2014). The roles of land tenure reforms and land markets in the context of population growth and land use intensification in Africa. Food Policy, 48, 88-97.

Holly Qu'an. (2:275-280). 
ISSN 2582-2292

Vol. 3, No. 03 May-June; 2021

Holtz, B. C., \& Harold, C. M. (2010). Interpersonal Justice and Deviance. http://www.camden.rutgers.edu/pdf/holtz.pdf.

Ibrahim, H., Zhou, J., Li, M., \& Chen, Q. (2014). Perception of Farmers on Extension Services in North Western Part of Nigeria: The Case of Farming Households in Nigeria. Journal of Service Science and Management, 2014.

Jayne, T. S., Chamberlin, J., \& Headey, D. D. (2014). Land pressures, the evolution of farming systems, and development strategies in Africa: A synthesis. Food Policy, 48, 1-17.

Jinjiri. R K., (2014). Perception of Nigerian Muslim account holders in conventional banks toward Islamic banking products. International Journal of Islamic and Middle Eastern Finance and Management, 7(3), 288-305.

Kan, I., Haim, D., Rapaport-Rom, M., \& Shechter, M. (2009). Environmental amenities and optimal agricultural land use: The case of Israel. Ecological Economics, 68(6), 1893-1898.

Nigeria Budget, 2015 (http://www.KanoState.gov.ng)

Nigeria Buget, 2016 and Nigeria map from Kano free encyloypedia (www.Kanostate.gov.ng)

King, R. G., \& Levine, R. (1993). Finance and growth: Schumpeter might be right. The quarterly journal of economics, 717-737.

Krejcie, R. V., \& Morgan, D. W. (1970). Determining Sample Size for Research Activities. Educational and Psychological Measurement, 30, 607-610.

Mastoor, S. A. (2014). Islamic Banking System in Afghanistan (No. 0200302). International Institute of Social and Economic Sciences.

Mattthew, A. O., \& Uchechukwu, A. A. (2014). Rural Farmers Sources and Use of Credit in Nsukka Local Government Area of Enugu State, Nigeria. Asian Journal of Agricultural Research, 8(4), 195-203.

Mohammed, A. I. Bashir A.A, 7 Ogunbado, T., (2016). The Viability of Salam Finance in the Growth of Agricultural Production in Nigeria, Nigeria. Asian Journal of Multidisciplinary Studies, $4(12)$.

Mohammed, H. S. E. A., \& Hussien, A. I. M. (2012). The Finance Of Wheat In Gezira Scheme, Sudan. International Working Paper Series Paper N.12/03.

Mohammed, S., Ibrahim, U. S., \& Abubakar, N. (2014). Effect of hike in food prices on household food expenditure in nigeria, Nigeria: a case of 2008 global food crisis. Agriculture And Biology Journal Of North America Issn Print: 2151-7517, Issn Online: 2151-7525

Mohsin, M. I. A. (2005). The practice of Islamic banking system in Sudan. Journal of Economic Cooperation, 26(4), 27-50.

Murphy, A. J. (2011). Farmers' markets as retail spaces. International Journal of Retail \& Distribution Management, 39(8), 582-597.

Mustapha I., F., (May, 2012). The Servant: A Nigeria Civil Service Newsmagazine Vol.5 No. 12.

National Population Commision (NPC) (2015): htt://countrymeters.info/en/

Ngaruko, D. D. (2014). Determinants of Demand for and Repayment of Bank loan in Economies with 
Market Coordination Failures: A Tanzanian context. African Journal of Economic Review, 2(2), 95-124.

Ngaruko, D. D. (2014). Determinants of Demand for and Repayment of Bank loan in Economies with

Market Coordination Failures: A Tanzanian context. African Journal of Economic Review, 2(2), 95-124.

Nigerian GDP, 2015 http://www.tradingeconomics.com/nigeria/gdp)

NPC (2015):Nigerian population commission census, htt: //country meters.info/en/Nigeria.

Nwosu, F. O., Oguoma, N. N. O., Ben-Chendo, N. G., \& Henri-Ukoha, A. (2010). The agricultural credit guarantee scheme: its roles, problems and prospects in Nigeria's quest for agricultural development. Researcher, 2, 87-90.

Obaidullah, M. (2015). Enhancing food security with Islamic microfinance: insights from some recent experiments. Agricultural Finance Review, 75(2), 142-168.

Obaidullah, M., \& Mohamed-Saleem, A. (2008). Innovations in Islamic microfinance: lessons from Muslim Aid's Sri Lankan experiment. Islamic Development Bank, Jeddah, KSA.

Odufote, B. O. (2012). Enhancing Credit Flow to the Agricultural Sector: The Case of Central Bank of Nigeria's Commercial Agriculture Credit Scheme (CACS) (No. 160460). African Farm Management Association (AFMA).

Ogunbado \& Ahmed (2015). Bay' Salam as an Islamic Financial Alternative for Agricultural Sustainability in Nigeria. Journal of Islamic Economics, Banking and Finance (JIEBF).Vol. 11, No 4.

Ommani, A. R. (2011). Influence Youth Interest To Become Agricultural Entrepreneur. http://ijbssnet.com/journals/Vol_4_No_3_March_2013/31.pdf.

Onyekuru, A. N. (2010). Review of Private Agricultural Advocacy Groups in Nigeria. International food policy institute. Policy Note No.27.

Onyenucheya, F., \& Ukoha, O. O. (2007). Loan repayment and credit worthiness of farmers under the Nigerian Agricultural Cooperative and Rural Development Bank (NACRDB). Agricultural Journal, 2(2), 265-270.

Otsuka, K., Liu, Y., \& Yamauchi, F. (2014). The Future of Small Farms in Asia. paper submitted to the Overseas Development Institute and International Fund for Agricultural Development.

Pallant, J. (2010). SPSS survival manual: A step by step guide to data analysis using SPSS (4th ed.). New York, NY: Open University Press.

Phillip, D., Nkonya, E., Pender, J., \& Oni, O. A. (2009). Constraints to increasing agricultural productivity in Nigeria: A review (No. 6). International Food Policy Research Institute (IFPRI).

Plusquellec, H. (1990). The Gezira irrigation scheme in Sudan. World Bank technical paper, (120).

Putri, M. A., \& Dewi, (2011). M. K. Developing Salam-Based Financing Product: Indonesian Islamic Rural Bank. Business \& Management Quarterly Review, 2(4), 103-112.

Rasouliazar, S., Hosseini, S. M., \& Mirdamadi, S. M. (2012). Factors influencing the design of 
agricultural advisory service network in the West Azerbaijan Province. International Journal of Agricultural Science and Research, 1(1), 59-66.

Ringle, C. M., Wende, S., \& Becker, J. M.(2014).SmartPLS 3. SmartPLS, Hamburg.

Saibu, M. O. (2010). Output Fluctuations And Macroeconomic Policy In Nigeria: Trends Analysis And Policy Implication For Attainment Of Needs And Mdgs In Nigeria. Oida International Journal Of Sustainable Development Vol 2 (2) Pp11, 26

Saqib, L., Nazeer, N., Khan, K., \& Zafar, M. A. (2013). Application of Islamic banking instrument (Murābaha) for sugarcane industry in developing countries. Journal of Islamic Economics, Banking and Finance, 9(1), 89-106.

Sardar, A., Azeem, M. M., Hassan, S., \& Bakhsh, K. (2013). Comparison of efficiency between pure Islamic banks and Islamic bank windows and role of Islamic banking in agriculture sector. Pak. J. Agri. Sci, 50(1), 155-161.

Sayım, F. (2015). The Participation Banking As a Distinctive Method and the Its Growing in the Turkish Finance Market-Period: 2007-2013. EMAJ: Emerging Markets Journal, 5(1), 93-111.

Siddiqi, M. N. (2006). Islamic banking and finance in theory and practice: A Survey of State of the Art. Islamic Economic Studies, 13(2), 1-48.

Simtowe, F., Zeller, M., \& Diagne, A. (2009). The impact of credit constraints on the adoption of hybrid maize in Malawi. Review of Agricultural and environmental studies, 90(1), 5-22.

Temu, A. E., Nyange, D., Mattee, A. Z., \& Kashasha, L. K. (2013). Assessing Rural Services, Social aminities and their Impact on Agricultural Producfion, Markefing and Food Security in Tanzania

The servant (2012). A Nigeria Civil Service Newsmagazine of May, 2012 (Vol.5.12)

Tibi, K., \& Edebiri, F. (2015). Access To Microcredit-A Sure Way Of Breaking The Vicious Circle Of Poverty Among Farmers In Ethiope East Local Government Area, Delta State, Nigeria. Vol-2, Issue-8 PP. 1275-1184

Trukhachev, V., Ivolga, A., \& Lescheva, M. (2014). Enhancement of Land Tenure Relations as a Factor of Sustainable Agricultural Development: Case of Stavropol Krai, Russia. Sustainability, 7(1), 164-179.

Ugwu, D. S., \& Kanu, I. O. (2012). Effects of agricultural reforms on the agricultural sector in Nigeria. Journal of African Studies and Development, 4(2), 51-59. 